\title{
Sensitivity of tropospheric oxidants to biomass burning emissions: implications for radiative forcing
}

\author{
Jingqiu Mao, ${ }^{1,2}$ Larry W. Horowitz, ${ }^{2}$ Vaishali Naik, ${ }^{3}$ Songmiao Fan, ${ }^{2}$ Junfeng Liu, ${ }^{4}$ and \\ Arlene M. Fiore ${ }^{5}$ \\ Received 6 November 2012; revised 22 January 2013; accepted 31 January 2013; published 26 March 2013.
}

[1] Biomass burning is one of the largest sources of trace gases and aerosols to the atmosphere and has profound influence on tropospheric oxidants and radiative forcing. Using a fully coupled chemistry-climate model (GFDL AM3), we find that co-emission of trace gases and aerosol from present-day biomass burning increases the global tropospheric ozone burden by $5.1 \%$ and decreases global mean $\mathrm{OH}$ by $6.3 \%$. Gas and aerosol emissions combine to increase $\mathrm{CH}_{4}$ lifetime nonlinearly. Heterogeneous processes are shown to contribute partly to the observed lower $\Delta \mathrm{O}_{3} /$ $\Delta \mathrm{CO}$ ratios in northern high latitudes versus tropical regions. The radiative forcing from biomass burning is shown to vary nonlinearly with biomass burning strength. At present-day emission levels, biomass burning produces a net radiative forcing of $-0.19 \mathrm{~W} / \mathrm{m}^{2}(-0.29$ from short-lived species, mostly aerosol direct and indirect effects, +0.10 from $\mathrm{CH}_{4}$ and $\mathrm{CH}_{4}$-induced changes in $\mathrm{O}_{3}$ and stratospheric $\mathrm{H}_{2} \mathrm{O}$ ) but increases emissions to over 5 times present levels would result in a positive net forcing. Citation: Mao, J., L. W. Horowitz, V. Naik, S. Fan, J. Liu, and A. M. Fiore (2013), Sensitivity of tropospheric oxidants to biomass burning emissions: implications for radiative forcing, Geophys. Res. Lett., 40, 1241-1246, doi:10.1002/grl.50210.

\section{Introduction}

[2] Biomass burning influences global oxidation capacity in complex ways, resulting from emissions of a mixture of trace gases and aerosols [Andreae and Merlet, 2001]. The trace gas emissions from wildfires produce ozone through the photochemical oxidation of carbon monoxide (CO) and hydrocarbons in the presence of nitrogen oxide $\left(\mathrm{NO}_{x}\right)$ [Mauzerall et al., 1998]. Meanwhile, emitted CO and hydrocarbons provide additional sinks for $\mathrm{OH}$ [Duncan et al., 2003a], extending the lifetime of methane $\left(\mathrm{CH}_{4}\right)$. Aerosol emissions

All Supporting Information may be found in the online version of this article.

${ }^{1}$ Program in Atmospheric and Oceanic Sciences, Princeton University, Princeton, New Jersey, USA.

${ }^{2}$ Geophysical Fluid Dynamics Laboratory/National Oceanic and Atmospheric Administration, Princeton, New Jersey, USA.

${ }^{3}$ UCAR/NOAA Geophysical Fluid Dynamics Laboratory/National Oceanic and Atmospheric Administration, Princeton, New Jersey, USA.

${ }^{4}$ College of Urban and Environmental Sciences, Peking University, Beijing, China.

${ }^{5}$ Department of Earth and Environmental Sciences and Lamont-Doherty Earth Observatory, Columbia University, Palisades, New York, USA.

Corresponding author: Jingqiu Mao, Program in Atmospheric and Oceanic Sciences, Princeton University, Princeton, NJ 08542, USA. (Jingqiu.Mao@noaa.gov)

(C)2013. American Geophysical Union. All Rights Reserved. 0094-8276/13/10.1002/grl.50210 can influence photochemistry directly by changing photolysis rates [Martin et al., 2003] and heterogeneous interaction with gas-phase species [Jacob, 2000; Pozzoli et al., 2008] and indirectly by induced changes in clouds [Jiang et al., 2012; Liao et al., 2009]. As a result, beside the direct and indirect effects from biomass burning aerosols, its influence on radiative forcing can be further complicated by the changes in greenhouse gases, including ozone, $\mathrm{CH}_{4}$ (via $\mathrm{OH}$ ), and stratospheric water vapor (via $\mathrm{CH}_{4}$ oxidation).

[3] An important feature of biomass burning is its significant inter-annual variability [Duncan et al., 2003a; Lamarque et al., 2010; Schultz et al., 2008; van der Werf et al., 2010], resulting from both natural and anthropogenic activities, such as El Niño, changes in land use, and population density [Field et al., 2009]. Akagi et al. [2011] estimate that the total fire emissions during El Niño years can be two times larger than other years. Meanwhile, considerable uncertainties remain in current estimates of biomass burning emission, with a range of a factor of 3 to 5 for individual species [Akagi et al., 2011; Bond et al., 2013]. We expect even greater uncertainties on constraining preindustrial biomass burning emissions [Mouillot et al., 2006] and predicting future emissions [Pechony and Shindell, 2010; Spracklen et al., 2009]. To take these into account, we conduct perturbation tests at different magnitude of emissions to quantify the impact of biomass burning on tropospheric oxidants. We then calculate the resulting changes in radiative forcing from aerosol effects and the change in tropospheric oxidant levels.

\section{Methodology}

[4] We use the Geophysical Fluid Dynamics Laboratory (GFDL) global chemistry-climate atmosphere model (AM3) for this study. Model physics and chemistry in AM3 are described in detail in Donner et al. [2011] and Naik et al. (V. Naik et al., Preindustrial to present day impact of changes in short-lived pollutant emissions on atmospheric composition and climate forcing, submitted to Journal of Geophysical Research: Atmospheres, 2012; hereinafter Naik et al., submitted). In particular, AM3 solves both tropospheric and stratospheric chemistry over the full domain, thus representing more realistic interactions between stratosphere and troposphere than many other global chemistry models. AM3 parameterizes aerosol activation into liquid cloud droplets [Ming et al., 2006] and computes the aerosol indirect effect from the increase of cloud albedo (first indirect effect), the increase of cloud lifetime (second indirect effect), and cloud evaporation from absorbing aerosols (semi-direct effect).

[5] We here incorporate recent updates of heterogeneous reactions, including $\mathrm{HO}_{2}, \mathrm{NO}_{2}, \mathrm{~N}_{2} \mathrm{O}_{5}$, and $\mathrm{NO}_{3}$, on the basis of work by Mao et al. [2013] and Jacob [2000] (Table S3 in 
Supporting Information). In particular, the new $\mathrm{HO}_{2}$ uptake scheme by aerosols $\left(\mathrm{HO}_{2} \rightarrow \mathrm{H}_{2} \mathrm{O}\right.$ with $\left.\gamma\left(\mathrm{HO}_{2}\right)=1\right)$ provides a much stronger sink of $\mathrm{HO}_{2}$ than previously thought, leading to a significant decrease of global $\mathrm{OH}$. We also allow aerosol uptake on all types of aerosols, compared to only sulfate in standard version of AM3. As a result, these updates on heterogeneous reactions lead to significant improvements to simulated CO concentrations (Figure S2) and also decreases the $\mathrm{N} / \mathrm{S}$ inter-hemispheric $\mathrm{OH}$ ratio from 1.16 [Naik et al., submitted] to 1.06 , in better agreement with the best estimate of 0.98 derived from methylchloroform observation [ $\mathrm{Krol}$ and Lelieveld, 2003]. In order to take into account the effect of aerosols on actinic fluxes and photolysis rates, we calculate photolysis rates using the Fast-JX module with online cloud and aerosol fields [Bian and Prather, 2002].

[6] Biomass burning and anthropogenic emissions in this study follow the emission inventory for year 2000 provided by Lamarque et al. [2010]. In particular, biomass burning emissions in the model include $\mathrm{CO}(459 \mathrm{Tg} / \mathrm{yr}, 37 \%$ of global total emission), $\mathrm{NO}_{x}(5.5 \mathrm{Tg} \mathrm{N} / \mathrm{yr}, 13 \%)$, NMVOC (37 Tg C/yr, 3.4\%), $\mathrm{SO}_{2}(1.9 \mathrm{Tg} \mathrm{S} / \mathrm{yr}, 3.6 \%), \mathrm{BC}(2.6 \mathrm{Tg} /$ $\mathrm{yr}, 34 \%)$, and $\mathrm{OC}(23.3 \mathrm{Tg} / \mathrm{yr}, 65 \%)$. Biogenic emissions follow a climatology dataset (precursors of ozone and their effects in the troposphere) for 2000 (http://accent.aero.jussieu.fr/POET.php), to avoid the added complexity from feedbacks of model meteorology on biogenic emissions. We prescribe the concentrations of well-mixed greenhouse gases, including $\mathrm{CO}_{2}, \mathrm{~N}_{2} \mathrm{O}, \mathrm{CH}_{4}$, and halocarbons, at their year 2000 values [Naik et al., submitted]. In particular, $\mathrm{CH}_{4}$ is held at $1751 \mathrm{ppb}$. We force the model with observed sea surface temperatures and sea-ice cover.

[7] We design five sets of simulations, multiplying the standard biomass burning emissions of aerosols and ozone precursors by a factor of $0,1,2,5$, and 10 , respectively, retaining the same geographic distribution. We conduct three model experiments in each set of simulations: both aerosol and gas emissions (BB), aerosol emissions only (BB_AERO), and gaseous emissions only (BB_GAS). We also conduct additional sensitivity simulations with heterogeneous reactions turned off in our model. For each experiment, we conduct a continuous six-year run (2000-2005) with annually repeating emissions; the first year is discarded as model spin-up, and we analyze results from the final 5 years of each simulation in the following sections.

\section{Perturbations to Tropospheric Oxidants}

[8] The perturbations to annual mean tropospheric $\mathrm{OH}, \mathrm{O}_{3}$ burden, odd-oxygen $\left(\mathrm{O}_{x}\right)$ production rates, $\mathrm{CO}$ burden, methane lifetime, and methyl chloroform lifetime resulting from changes to biomass burning are shown in Figure 1. We focus on annual mean results because seasonal variations are found to be relatively small. We define the chemical troposphere as the atmospheric region where ozone is less than $150 \mathrm{ppb}$, following Prather et al. [2001]. The calculation of global $\mathrm{OH}$, methane lifetime, and methyl chloroform lifetime follows the air mass-weighted approach [Lawrence et al., 2001]. In the base run (1BB, naming is described in Table S4), massweighted global tropospheric $\mathrm{OH}$ is $9.8 \times 10^{5}$ molecules $\mathrm{cm}^{-3}$, lower than $10.5 \times 10^{5}$ molecules $\mathrm{cm}^{-3}$ calculated in Naik et al. (submitted), as a result of the updates described in previous section. The calculated methane lifetime and methyl chloroform lifetime against loss by tropospheric $\mathrm{OH}$ are 9.8 years and 5.8 years respectively in the base run (1BB), also longer than 8.5 years and 5.3 years in Naik et al. (submitted).

[9] Trace gas and aerosol emissions have opposite effects on global ozone burden and ozone production rate (Figures $1 \mathrm{~b}$ and 1c). While trace gas emissions tend to increase global ozone burden and ozone production rate, aerosol emissions tend to decrease global ozone burden, mainly due to heterogeneous processes. The net effect on global ozone burden is an increase of $5.3 \%$ from $0 \mathrm{BB}$ to $1 \mathrm{BB}$ (Figure $1 \mathrm{~b}$ ). In contrast to the impact on ozone, both trace gas and aerosol emissions lead to a decrease of global OH (Figure 1a).

[10] Aerosol emissions influence global $\mathrm{OH}$ and ozone directly via photolysis and heterogeneous processes. The effect of biomass burning aerosols on photolysis rates is found to have only a minimal impact on global oxidant burdens. In separate runs with heterogeneous chemistry turned off (not shown), we find that global $\mathrm{OH}$ and ozone are not sensitive to aerosol emissions from biomass burning. This small global effect likely results from a cancelation between the suppression of ozone production in source regions and its enhancement downstream. Similar conclusions were found previously by Jonson et al. [2000] and Bian et al. [2003]. It should be noted that regional impacts, however, can still be significant [Martin et al., 2003]. The indirect effect of aerosols on clouds appears to have minimal impacts on tropospheric oxidants, as it is limited by the small mass fraction of the atmosphere actually occupied by cloud [Jacob, 2000]. Therefore, the impact from aerosol emissions is mainly driven by heterogeneous processes.

[11] We now proceed to evaluate the effects of combined trace gas and aerosol emissions. Global mean $\mathrm{OH}$ decreases by $6.3 \%$ when biomass burning emissions are doubled from $1 \mathrm{BB}$ to $2 \mathrm{BB}$. The magnitude of this perturbation is in general consistent with previous direct and indirect estimates for the 1997 Indonesia fire, as a typical El Niño year with biomass burning emissions doubled [Akagi et al., 2011]. Duncan et al. [2003b] shows from a model study that global mean $\mathrm{OH}$ decreases by $6 \%$ in October and November of 1997. Prinn et al. [2005] shows from the inverse modeling of methyl chloroform that global $\mathrm{OH}$ dropped by $6 \%$ in 1997-1999 relative to 1978-2004 average values.

[12] $\mathrm{CH}_{4}$ lifetime and $\mathrm{CH}_{3} \mathrm{CCl}_{3}$ lifetime are considerably enhanced by the co-emitted gas and aerosol emissions (Figures $1 \mathrm{e}$ and $1 \mathrm{f}$ ). We find that $\mathrm{CH}_{4}$ lifetime increases only by 0.18 year and 0.30 year from $0 \mathrm{BB}$ to $1 \mathrm{BB}$ GAS and 1BB_AERO, respectively. However, the combination of both emissions leads to the increase of methane lifetime by 0.58 year (from $0 \mathrm{BB}$ to $1 \mathrm{BB}$ ), greater than the arithmetic sum of impacts from separate aerosol and gas emissions. In fact, this nonlinear effect becomes more significant with increasing magnitude of biomass burning emissions. We find that the co-emission leads to an increase of $\mathrm{CH}_{4}$ lifetime by 4.0 years from $0 \mathrm{BB}$ to $5 \mathrm{BB}$, in contrast to 1.2 years from $0 \mathrm{BB}$ to 5BB_AERO and 1.6years from 0BB to 5BB_GAS. Such nonlinearity is mainly due to the extended lifetime of $\mathrm{CO}$ (and other VOCs) in biomass burning plumes, resulting from aerosol uptake. This leads to significant increase of global $\mathrm{CO}$ burden (Figure 1d), which in turn further reduces global $\mathrm{OH}$.

[13] Another prominent feature in Figure 1 is the linearity of tropospheric ozone burden versus biomass burning emissions, reflecting $\mathrm{NO}_{x}$-limited $\mathrm{O}_{3}$ production on a global scale. This linearity is largely determined by the high $\mathrm{VOC} / \mathrm{NO}_{x}$ ratio of wildfire emissions, as ozone production 


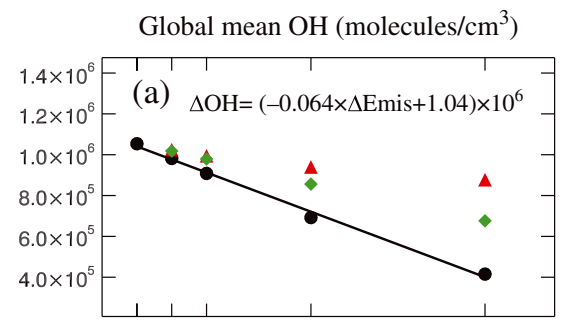

Global Ox proudction ( $\mathrm{Tg} / \mathrm{yr})$

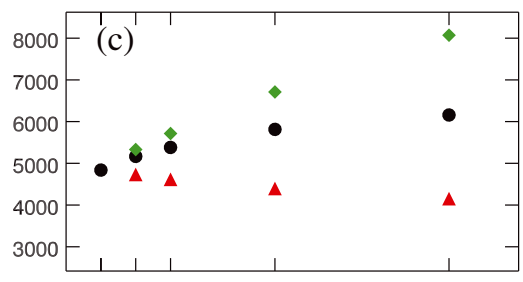

Methane lifetime (yrs)

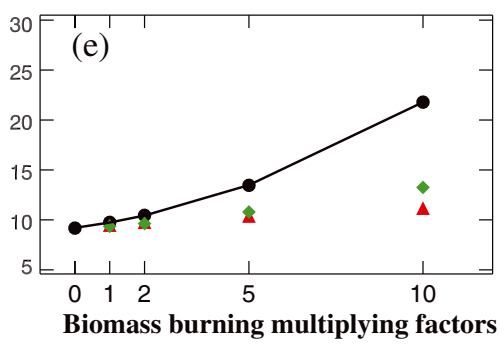

Global ozone burden (Tg)

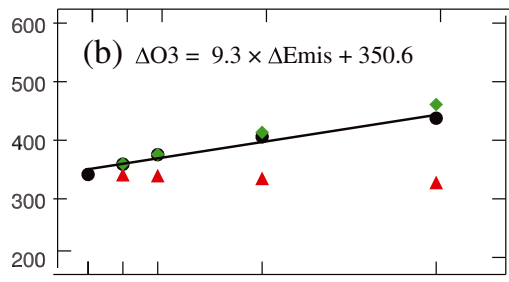

Global CO burden (Tg)

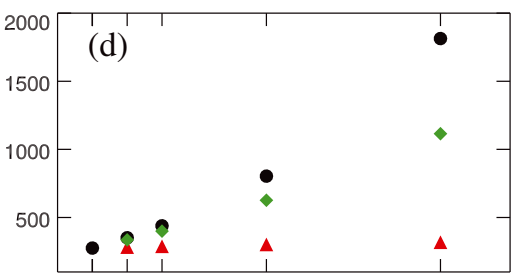

Methyl Chloroform lifetime (yrs)

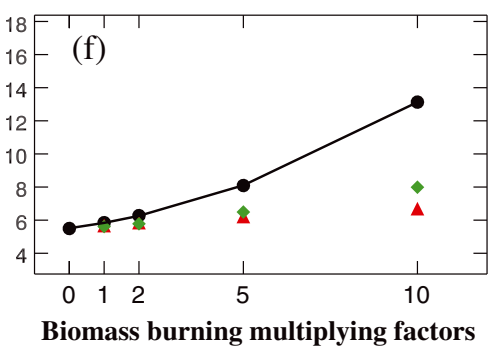

- BB

^ BB_AERO

- BB_GAS

Figure 1. Perturbation to global oxidation capacity by the magnitude of biomass burning emissions, including (a) global mean $\mathrm{OH}$ (molecules $/ \mathrm{cm}^{3}$ ), (b) global ozone burden (Tg), (c) global $\mathrm{O}_{x}$ production rate $(\mathrm{Tg} / \mathrm{yr})$, (d) global $\mathrm{CO}$ burden (Tg), (e) methane lifetime (years), and (f) methyl chloroform lifetime (years). Black circles are the runs with both gaseous and aerosol emissions (aerosol and gas). Red triangles are the runs with zero gas species emissions from biomass burning (aerosol only). Green diamonds are the runs with zero aerosol emissions from biomass burning (gas only). Solid line shows least square linear fit to "BB" simulation points in Figures $1 \mathrm{a}$ and $1 \mathrm{~b}$ and connects estimated lifetimes in Figures $1 \mathrm{e}$ and $1 \mathrm{f}$. Here $\mathrm{O}_{x}$ is defined as $\mathrm{O}_{3}+\mathrm{NO}_{2}+2 * \mathrm{NO}_{3}+3 * \mathrm{~N}_{2} \mathrm{O}_{5} . \mathrm{O}_{x}$ production rate is then defined as the sum of $\mathrm{HO}_{2}+\mathrm{NO}$ and $\mathrm{RO}_{2}+\mathrm{NO}$ reaction rates.

efficiency is weakly dependent on VOC or CO levels [Wang and Jacob, 1998]. Similar linearity of ozone responses was found for perturbation tests of individual $\mathrm{CO}$ and NMVOC emissions [Wu et al., 2009] and $\mathrm{CH}_{4}$ emissions [Fiore et al., 2008]. The approximate linearity justifies the additivity of the forcings from $\mathrm{CH}_{4}$-induced $\mathrm{O}_{3}$ as described below.

\section{Ozone Production Efficiency $\left(\Delta \mathrm{O}_{3} / \Delta \mathrm{CO}\right)$}

[14] The enhancement ratio $\Delta \mathrm{O}_{3} / \Delta \mathrm{CO}$ has been measured extensively as a metric to characterize $\mathrm{O}_{3}$ production efficiency from fire plumes. Previous measurements indicate significantly higher $\Delta \mathrm{O}_{3} / \Delta \mathrm{CO}$ ratios in tropical regions $(0.63 \pm 0.19)$ than northern high latitudes $(0.22 \pm 0.23)$ for aged fire plumes ( $\geq 5$ days) [Jaffe and Wigder, 2012]. Using global measurements of $\Delta \mathrm{O}_{3} / \Delta \mathrm{CO}$ ratios, Jaffe and Wigder [2012] estimated global ozone production rates to be 174 $\mathrm{Tg} / \mathrm{yr}$ from biomass burning, using emissions from Global Fire Emissions Database 3(GFED3) [van der Werf et al., 2010]. In contrast, our model shows a higher increase of global ozone production (328 Tg/yr) from $0 \mathrm{BB}$ to $1 \mathrm{BB}$ (Figure 1c). However, this rate increases to $617 \mathrm{Tg} / \mathrm{yr}$ with all heterogeneous reactions turned off (not shown), suggesting the importance of heterogeneous processes in suppressing ozone production.

[15] We here use the difference of annual mean burden between $0 \mathrm{BB}$ and $1 \mathrm{BB}$, to examine modeled $\Delta \mathrm{O}_{3} / \Delta \mathrm{CO}$ in four latitude bands (90S-10S, $10 \mathrm{~S}-30 \mathrm{~N}, 30 \mathrm{~N}-60 \mathrm{~N}$, and $60 \mathrm{~N}-90 \mathrm{~N})$ as categorized in Jaffe and Wigder [2012]. In the annual mean, we assume that the long-range transport from low latitudes to high latitudes has little influence on the latitudinal gradient of $\Delta \mathrm{O}_{3} / \Delta C O$, which is instead mainly driven by local chemical changes within each latitude band. This simplistic approach allows us to examine $\Delta \mathrm{O}_{3} / \Delta C O$ from a model perspective. As shown in Figure 2, $\Delta \mathrm{O}_{3} /$ $\Delta \mathrm{CO}$ decreases significantly in all latitude bands as a result of including aerosol uptake.

[16] Another remarkable feature in Figure 2 is that we see the opposite latitudinal gradient of $\Delta \mathrm{O}_{3} / \Delta \mathrm{CO}$ in northern hemisphere when heterogeneous chemistry is turned off. With heterogeneous chemistry turned on, however, $\Delta \mathrm{O}_{3} / \Delta \mathrm{CO}$ decreases from 0.25 to 0.16 from $10 \mathrm{~S}-30 \mathrm{~N}$ to $60 \mathrm{~N}-90 \mathrm{~N}$ band, suggesting that heterogeneous chemistry is at least partly responsible for this observed discrepancy of $\Delta \mathrm{O}_{3} / \Delta \mathrm{CO}$ between the tropics and northern high latitudes [Jaffe and Wigder, 2012]. We attribute this suppression of ozone production to two causes. First, $\mathrm{HO}_{2}$ uptake by aerosols can be 


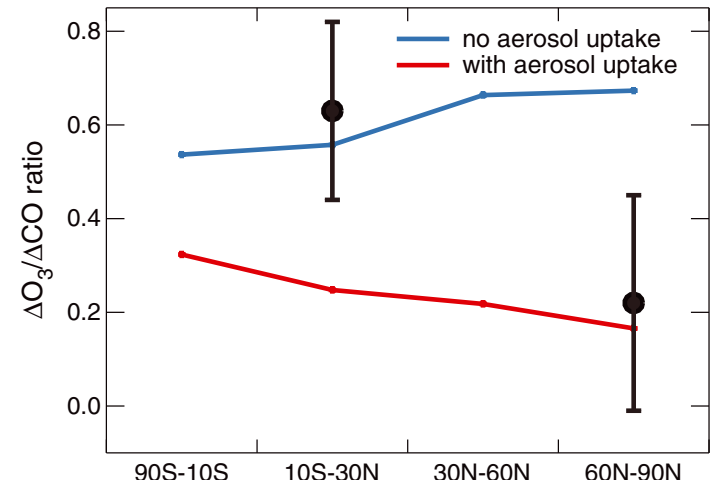

Figure 2. Comparison of observed and modeled $\Delta \mathrm{O}_{3} / \Delta \mathrm{CO}$ ratios. Observations (black solid circles with vertical bars) are from Jaffe and Wigder [2012]. Model ratios are calculated from the difference between $0 \mathrm{BB}$ and $1 \mathrm{BB}$ in annual mean burden of $\mathrm{O}_{3}$ and $\mathrm{CO}$ when aerosol uptake is on (red solid lines) and off (blue solid lines).

increasingly important at high latitudes as a $\mathrm{HO}_{x}$ sink, because of the quadratic dependence of the gas-phase $\mathrm{HO}_{x} \operatorname{sink}\left(\mathrm{HO}_{2}+\right.$ $\mathrm{HO}_{2}$ ) on $\mathrm{HO}_{2}$ concentrations and the strong decrease of $\mathrm{HO}_{2}$ concentrations towards high latitudes driven by solar zenith angle and water supply [Logan et al., 1981]. Second, the sink of $\mathrm{NO}_{x}$ through heterogeneous uptake of $\mathrm{N}_{2} \mathrm{O}_{5}, \mathrm{NO}_{3}$, and $\mathrm{NO}_{2}$ becomes increasingly important relative to $\mathrm{OH}+\mathrm{NO}_{2}$ at high latitudes [Dentener and Crutzen, 1993; Macintyre and Evans, 2010]. We emphasize here that this impact is driven by the heterogeneous chemistry on all types of aerosols. This latitudinal gradient of $\Delta \mathrm{O}_{3} / \Delta \mathrm{CO}$ has important implications for understanding the ozone radiative forcing induced by biomass burning.

\section{Radiative Forcing}

[17] We now examine the radiative forcing, defined here as the change of top-of-the-atmosphere (TOA) net radiative flux (shortwave and longwave), due to biomass burning perturbations. Figure 3a shows the change of TOA net radiative forcing relative to a state without biomass burning (0BB). While trace gas emissions exert a slight positive forcing of $+0.03 \mathrm{~W} \mathrm{~m}^{-2}$ (from $0 \mathrm{BB}$ to 1BB_GAS) as a result of the increase in ozone, aerosol emissions exert a negative forcing of $-0.46 \mathrm{~W} \mathrm{~m}^{-2}$ (from 0BB to 1BB_AERO), due to both aerosol direct and indirect effects. Therefore, the combined emission of trace gases and aerosols (from 0BB to $1 \mathrm{BB}$ ) is dominated by the effect of aerosols, producing a negative forcing of $-0.29 \mathrm{~W} \mathrm{~m}^{-2}$ (Figure 3a). This forcing is consistent with a recent estimate of total forcing from open burning $\left(-0.28 \mathrm{~W} \mathrm{~m}^{-2}\right)$ by Bond et al. [2013].

[18] Since our simulations hold $\mathrm{CH}_{4}$ fixed, we cannot directly assess the radiative forcing that would result from the $\mathrm{CH}_{4}$ changes induced by direct biomass burning emissions of $\mathrm{CH}_{4}$ or by perturbations to tropospheric oxidants (and, thus, to $\mathrm{CH}_{4}$ lifetime). After adjusting the changes in oxidants and to $\mathrm{CH}_{4}$ emission changes from biomass burning, we estimate the steady state $\mathrm{CH}_{4}$ mixing ratios to be 1506,2050 , and $3432 \mathrm{ppb}$ for $0 \mathrm{BB}, 2 \mathrm{BB}$, and $5 \mathrm{BB}$, respectively (section S7 in Supporting Information), compared to a present-day value of $1751 \mathrm{ppb}$ in $1 \mathrm{BB}$. The radiative forcing due to the changes of $\mathrm{CH}_{4}$ mixing ratios (CH4_ss forcing) is calculated following the formulation of Ramaswamy et al. [2001]. We show in Figure $3 b$ that the resulting change in net radiative forcing (versus $0 \mathrm{BB}$ ) is $0.09,0.20$, and 0.60 $\mathrm{W} \mathrm{m}{ }^{-2}$ for $1 \mathrm{BB}, 2 \mathrm{BB}$, and $5 \mathrm{BB}$, respectively. This net radiative forcing $\left(0.09 \mathrm{~W} \mathrm{~m}^{-2}\right)$ is comparable to a recent estimate $\left(0.05-0.13 \mathrm{~W} \mathrm{~m}^{-2}\right)$ by Ward et al. [2012].
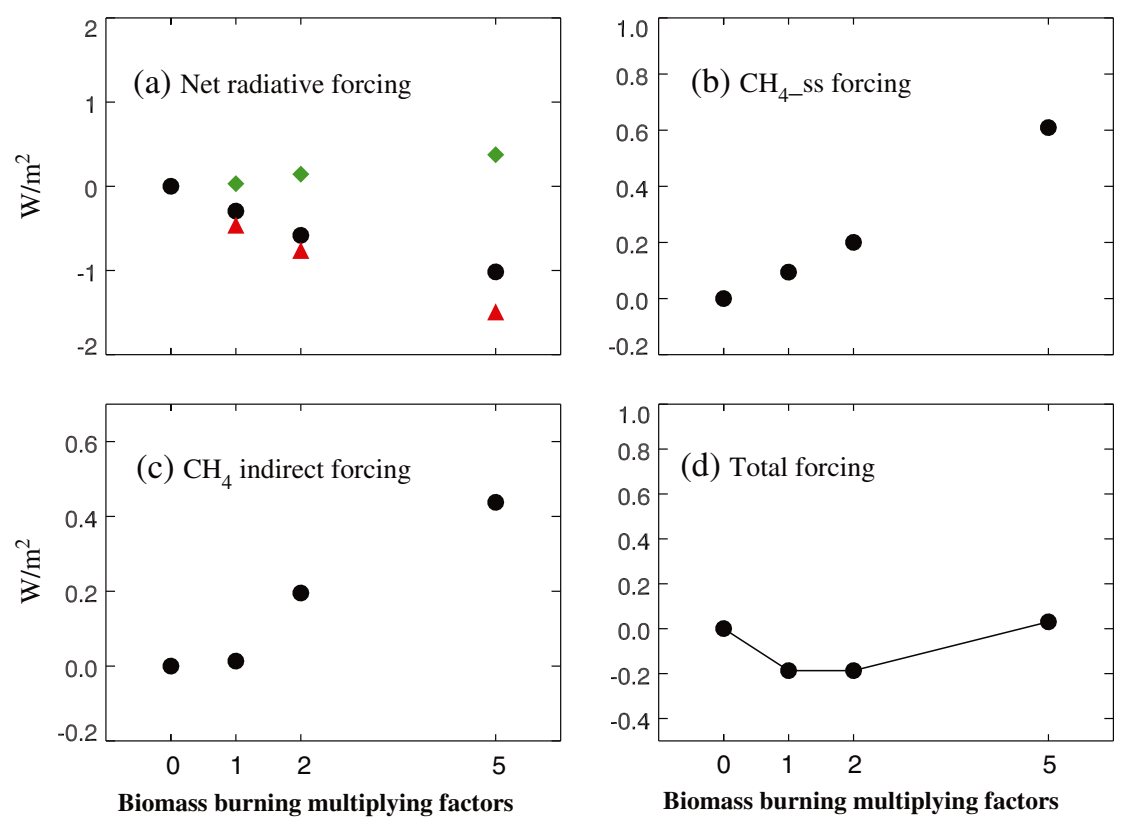

Biomass burning multiplying factors

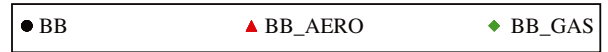

Figure 3. Response of net radiative forcing from perturbations of biomass burning emissions relative to a state without biomass burning (0BB), including (a) the combined rapid forcing from aerosols and ozone with fixed $\mathrm{CH}_{4}$ concentrations, (b) the forcing from the estimated steady state change in $\mathrm{CH}_{4}$, and (c) the indirect forcing due to $\mathrm{CH}_{4}$-induced $\mathrm{O}_{3}$ and stratospheric $\mathrm{H}_{2} \mathrm{O}$ and (d) the total forcing. The simulation of $10 \mathrm{BB}$ is not shown. 
[19] If the chemical system were allowed to respond to these estimated perturbations to $\mathrm{CH}_{4}$ concentration, $\mathrm{O}_{3}$ and stratospheric $\mathrm{H}_{2} \mathrm{O}$ would change, leading to a further radiative forcing. To take into account this indirect forcing resulting from the $\mathrm{CH}_{4}$-induced $\mathrm{O}_{3}$ change and stratosphere $\mathrm{H}_{2} \mathrm{O}$ change, we conduct additional AM3 simulations in the $1 \mathrm{BB}$ condition but with new prescribed $\mathrm{CH}_{4}$ concentrations (1506, 2050, and $3432 \mathrm{ppb}$ ) as described above. The change of net radiative forcing from $\mathrm{O}_{3}$ and $\mathrm{H}_{2} \mathrm{O}$ is considered as the $\mathrm{CH}_{4}$ indirect forcing resulting from the $\mathrm{CH}_{4}$-induced $\mathrm{O}_{3}$ change and stratosphere $\mathrm{H}_{2} \mathrm{O}$ change $\left(\mathrm{CH}_{4}\right.$ indirect forcing). We show in Figure $3 \mathrm{c}$ that the $\mathrm{CH}_{4}$ indirect radiative forcing is $0.01,0.20$, and $0.44 \mathrm{~W} \mathrm{~m}^{-2}$ in the $1 \mathrm{BB}, 2 \mathrm{BB}$, and $5 \mathrm{BB}$ simulations (versus $0 \mathrm{BB}$ ), respectively. Our calculated radiative forcings from $\mathrm{CH}_{4}$-induced changes are comparable to other model studies [Isaksen et al., 2011].

[20] Figure 3d shows the sum of net radiative forcing from ozone and aerosols (Figure $3 \mathrm{a}), \mathrm{CH}_{4}$ perturbations (Figure $3 \mathrm{~b}$ ), and $\mathrm{CH}_{4}$ indirect forcing (Figure $3 \mathrm{c}$ ). We see that when the perturbation of biomass burning is larger than factor of 5, the indirect warming from $\mathrm{CH}_{4}$ (Figures $3 \mathrm{~b}$ and $3 \mathrm{c}$ ) dominates over the direct cooling from emissions (Figure 3a), leading to a net warming effect from biomass burning. Despite the large uncertainties in current estimates of direct radiative forcing from biomass burning aerosols $\left(+0.03 \pm 0.12 \mathrm{~W} \mathrm{~m}^{-2}\right)$ [Forster et al., 2007], we show that the warming resulting from $\mathrm{CH}_{4}$ and $\mathrm{CH}_{4}$-induced changes in $\mathrm{O}_{3}$ and stratospheric $\mathrm{H}_{2} \mathrm{O}$, which can be considered as an indirect chemical forcing, is comparable to the cooling from biomass burning aerosols with direct and indirect effect taken into account.

\section{Conclusion and Discussion}

[21] Trace gases and aerosols are intrinsically co-emitted by biomass burning. We show here that this co-emission leads to a net increase in tropospheric ozone production and ozone burden, a decrease in global mean $\mathrm{OH}$, and a nonlinear increase of $\mathrm{CH}_{4}$ lifetime, exceeding the arithmetic sum of separate aerosol and gas effects by more than $20 \%$, mainly due to heterogeneous processes. We also show that heterogeneous chemistry contributes to the observed lower $\Delta \mathrm{O}_{3} / \Delta \mathrm{CO}$ ratios in northern high latitudes versus tropical regions. The implied radiative forcings from the change in steady state $\mathrm{CH}_{4}$ concentrations, and from $\mathrm{CH}_{4}$-induced change in $\mathrm{O}_{3}$ and stratospheric $\mathrm{H}_{2} \mathrm{O}$, are comparable to the direct and indirect forcing from biomass burning aerosols.

[22] In fact, our estimate of warming effect from biomass burning emissions could be biased low. First, we have not considered $\mathrm{CO}_{2}$ and $\mathrm{N}_{2} \mathrm{O}$ emissions from biomass burning in this study, which would lead to further warming [Ward et al., 2012]. Second, we may severely underestimate the NMVOC emissions as demonstrated by a recent study [Akagi et al., 2011], which would lead to further increase of ozone and decrease of global $\mathrm{OH}$. Further, the decrease of global $\mathrm{OH}$ will also lead to the increase of hydrochlorofluorocarbons (HCFCs) and hydrofluorocarbons (HFCs), which would also contribute to warming. Therefore, the assessment of radiative forcing from biomass burning must consider the indirect chemical forcing from its perturbation to tropospheric oxidants. In particular, a better understanding of heterogeneous chemistry would be of great importance for assessing the role of aerosols in climate system.
[23] Acknowledgments. We thank Paul Ginoux, Meiyun Lin, and two anonymous reviewers for helpful comments. We thank Drew T. Shindell for providing MOPITT CO data.

\section{References}

Akagi, S. K., R. J. Yokelson, C. Wiedinmyer, M. J. Alvarado, J. S. Reid, T. Karl, J. D. Crounse, and P. O. Wennberg (2011), Emission factors for open and domestic biomass burning for use in atmospheric models, Atmos. Chem. Phys., 11(9), 4039-4072.

Andreae, M. O., and P. Merlet (2001), Emission of trace gases and aerosols from biomass burning, Global Biogeochem. Cycles, 15(4), 955-966.

Bian, H., and M. J. Prather (2002), Fast-J2: Accurate simulation of stratospheric photolysis in global chemical models, J. Atmos. Chem., 41(3), 281-296.

Bian, H., M. J. Prather, and T. Takemura (2003), Tropospheric aerosol impacts on trace gas budgets through photolysis, J. Geophys. Res., 108 (D8), 4242

Bond, T. C., et al. (2013), Bounding the role of black carbon in the climate system: A scientific assessment, J. Geophys. Res. Atmos., doi:10.1002/ jgrd.50171.

Dentener, F. J., and P. J. Crutzen (1993), Reaction of N2O5 on tropospheric aerosols: Impact on the global distributions of $\mathrm{NO}_{x}, \mathrm{O} 3$, and $\mathrm{OH}$, J. Geophys. Res., 98(D4), 7149-7163.

Donner, L. J., et al. (2011), The dynamical core, physical parameterizations, and basic simulation characteristics of the atmospheric component AM3 of the GFDL global coupled model CM3, J. Climate, 24 (13), 3484-3519.

Duncan, B. N., R. V. Martin, A. C. Staudt, R. Yevich, and J. A. Logan (2003a), Interannual and seasonal variability of biomass burning emissions constrained by satellite observations, J. Geophys. Res. Atmos., 108(D2), 4100, doi:10.1029/2002JD002378.

Duncan, B. N., I. Bey, M. Chin, L. J. Mickley, T. D. Fairlie, R. V. Martin, and H. Matsueda (2003b), Indonesian wildfires of 1997: Impact on tropospheric chemistry, J. Geophys. Res. Atmos., 108(D15), 4458, doi:10.1029/2002JD003195.

Field, R. D., G. R. van der Werf, and S. S. P. Shen (2009), Human amplification of drought-induced biomass burning in Indonesia since 1960, Nat Geosci., 2(3), 185-188.

Fiore, A. M., J. J. West, L. W. Horowitz, V. Naik, and M. D. Schwarzkopf (2008), Characterizing the tropospheric ozone response to methane emission controls and the benefits to climate and air quality, J. Geophys. Res., 113(D8), D08307, doi:10.1029/2007JD009162.

Forster, P., et al. (2007), Changes in Atmospheric Constituents and in Radiative Forcing, edited, Cambridge University Press, Cambridge, United Kingdom and New York, USA

Isaksen, I. S. A., M. Gauss, G. Myhre, K. M. Walter Anthony, and C. Ruppel (2011), Strong atmospheric chemistry feedback to climate warming from Arctic methane emissions, Global Biogeochem. Cycles, 25(2), GB2002, doi:10.1029/2010GB003845.

Jacob, D. J. (2000), Heterogeneous chemistry and tropospheric ozone, Atmos. Environ., 34(12-14), 2131-2159.

Jaffe, D. A., and N. L. Wigder (2012), Ozone production from wildfires: A critical review, Atmos. Environ., 51(0), 1-10.

Jiang, X., C. Wiedinmyer, and A. G. Carlton (2012), Aerosols from fires: An examination of the effects on ozone photochemistry in the Western United States, Environ. Sci. Technol., 46(21), 11878-11886.

Jonson, J. E., A. Kylling, T. K. Berntsen, I. S. A. Isaksen, C. S. Zerefos, and K. Kourtidis (2000), Chemical effects of UV fluctuations inferred from total ozone and tropospheric aerosol variations, J. Geophys. Res., 105 (D11), 14561-14574.

Krol, M., and J. Lelieveld (2003), Can the variability in tropospheric $\mathrm{OH}$ be deduced from measurements of 1,1,1-trichloroethane (methyl chloroform)?, J. Geophys. Res., 108(D3), 4125.

Lamarque, J. F., et al. (2010), Historical (1850-2000) gridded anthropogenic and biomass burning emissions of reactive gases and aerosols: Methodology and application, Atmos. Chem. Phys., 10(15), 7017-7039.

Lawrence, M. G., P. Jockel, and R. von Kuhlmann (2001), What does the global mean $\mathrm{OH}$ concentration tell us?, Atmos. Chem. Phys., 1, 37-49.

Liao, H., Y. Zhang, W.-T. Chen, F. Raes, and J. H. Seinfeld (2009), Effect of chemistry-aerosol-climate coupling on predictions of future climate and future levels of tropospheric ozone and aerosols, J. Geophys. Res. Atmos., 114(D10), D10306, doi:10.1029/2008JD010984.

Logan, J. A., M. J. Prather, S. C. Wofsy, and M. B. McElroy (1981), Tropospheric chemistry: A global perspective, J. Geophys. Res., 86 (C8), 7210-7254.

Macintyre, H. L., and M. J. Evans (2010), Sensitivity of a global model to the uptake of $\mathrm{N} 2 \mathrm{O} 5$ by tropospheric aerosol, Atmos. Chem. Phys., 10 (15), 7409-7414. 


\section{MAO ET AL: BIOMASS BURNING ON OXIDANTS AND FORCING}

Mao, J., S. Fan, D. J. Jacob, and K. R. Travis (2013), Radical loss in the atmosphere from $\mathrm{Cu}-\mathrm{Fe}$ redox coupling in aerosols, Atmos. Chem. Phys., 13(2), 509-519.

Martin, R. V., D. J. Jacob, R. M. Yantosca, M. Chin, and P. Ginoux (2003), Global and regional decreases in tropospheric oxidants from photochemical effects of aerosols, J. Geophys. Res. Atmos., 108(D3), doi:10.1029/ 2002JD002622.

Mauzerall, D. L., J. A. Logan, D. J. Jacob, B. E. Anderson, D. R. Blake, J. D. Bradshaw, B. Heikes, G. W. Sachse, H. Singh, and B. Talbot (1998), Photochemistry in biomass burning plumes and implications for tropospheric ozone over the tropical South Atlantic, J. Geophys. Res., 103(D7), 8401-8423.

Ming, Y., V. Ramaswamy, L. J. Donner, and V. T. J. Phillips (2006), A new parameterization of cloud droplet activation applicable to general circulation models, J. Atmos. Sci., 63(4), 1348-1356.

Mouillot, F., A. Narasimha, Y. Balkanski, J.-F. Lamarque, and C. B. Field (2006), Global carbon emissions from biomass burning in the 20th century, Geophys. Res. Lett., 33(1), L01801, doi:10.1029/ 2005 GL024707.

Pechony, O., and D. T. Shindell (2010), Driving forces of global wildfires over the past millennium and the forthcoming century, Proc. Natl. Acad. Sci., 107(45), 19167-19170.

Pozzoli, L., I. Bey, S. Rast, M. G. Schultz, P. Stier, and J. Feichter (2008), Trace gas and aerosol interactions in the fully coupled model of aerosolchemistry-climate ECHAM5-HAMMOZ: 2. Impact of heterogeneous chemistry on the global aerosol distributions, J. Geophys. Res., 113, D07309, doi:10.1029/2007JD009008.

Prather, M., et al. (2001), Atmospheric chemistry and greenhouse gases, in Climate Change 2001: The Scientific Basis, edited by J. T. Houghton, et al., pp. 239-287, Cambridge Univ. Press, New York.
Prinn, R. G., et al. (2005), Evidence for variability of atmospheric hydroxyl radicals over the past quarter century, Geophys. Res. Lett., 32, L07809, doi:10.1029/2004GL022228.

Ramaswamy, V., et al. (2001), Radiative Forcing of Climate Change, in Climate Change 2001: The Scientific Basis, edited by J. T. Houghton, et al., pp. 351-416, Cambridge Univ. Press, New York.

Schultz, M. G., A. Heil, J. J. Hoelzemann, A. Spessa, K. Thonicke, J. G. Goldammer, A. C. Held, J. M. C. Pereira, and M. van het Bolscher (2008), Global wildland fire emissions from 1960 to 2000, Global Biogeochem. Cycles, 22, GB2002, doi:10.1029/2007GB003031.

Spracklen, D. V., L. J. Mickley, J. A. Logan, R. C. Hudman, R. Yevich, M. D. Flannigan, and A. L. Westerling (2009), Impacts of climate change from 2000 to 2050 on wildfire activity and carbonaceous aerosol concentrations in the western United States, J. Geophys. Res., 114, D20301, doi:10.1029/2008JD010966.

van der Werf, G. R., J. T. Randerson, L. Giglio, G. J. Collatz, M. Mu, P. S. Kasibhatla, D. C. Morton, R. S. DeFries, Y. Jin, and T. T. van Leeuwen (2010), Global fire emissions and the contribution of deforestation, savanna, forest, agricultural, and peat fires (1997-2009), Atmos. Chem. Phys., 10(23), $11707-11735$

Wang, Y. H., and D. J. Jacob (1998), Anthropogenic forcing on tropospheric ozone and $\mathrm{OH}$ since preindustrial times, J. Geophys. Res. Atmos., 103(D23), 31123-31135.

Ward, D. S., S. Kloster, N. M. Mahowald, B. M. Rogers, J. T. Randerson, and P. G. Hess (2012), The changing radiative forcing of fires: global model estimates for past, present and future, Atmos. Chem. Phys., 12(22), 10857-10886.

Wu, S. L., B. N. Duncan, D. J. Jacob, A. M. Fiore, and O. Wild (2009), Chemical nonlinearities in relating intercontinental ozone pollution to anthropogenic emissions, Geophys. Res. Lett., 36, L05806, doi:10.1029/ 2008 GL036607. 